\title{
Comparative Study of Groundwater Pollution of M'nasra and Sfafaa zones (Gharb, Morocco) by Nitrates
}

\author{
Najib EL KHODRANI*1,4, Serine OMRANIA ${ }^{2}$, Abdrrahim NOUAYTI ${ }^{3}$, Abdelmajid ZOUAHRI ${ }^{1}$, Ahmed $^{2}$ \\ DOUAIK $^{1}$, Hamza IAAICH ${ }^{1}$, Mbark LAHMAR ${ }^{1}$, and Mohammed FEKHAOUI ${ }^{4}$ \\ ${ }^{I}$ Research Unit on Environment and Conservation of Natural Resources, Regional Center of Rabat, National Institute of \\ Agricultural Research (INRA), Rabat, Morocco. \\ ${ }^{2}$ Laboratory of Spectroscopy, Molecular Modeling, Materials, Nanomaterials, Waters and Environment, CERNE2D, Faculty \\ of Sciences, Mohammed V University, Rabat, Morocco. \\ ${ }^{3}$ Laboratory of Applied Geosciences, Faculty of Sciences, University Mohamed First Oujda 60000, Morocco. \\ ${ }^{4}$ Scientific Institute, Mohammed V University, Rabat, Morocco.
}

\begin{abstract}
The quality of water resources in Morocco is degraded by pollution from agriculture, industry and urbanization. In this work we have realized a comparative study of two groundwater pollution zones: M'nasra (Kenitra) and Sfafaa (Sidi Slimane). In general, the results of this study showed that most water wells are strongly mineralized as the conductivity far exceeds the standard of drinking water. Sodium chloride $(\mathrm{NaCl})$ concentration is between 33.9 and $1184.6 \mathrm{mg} / 1$ and shows some of the wells are loaded with salts. The $\mathrm{pH}$ is generally basic in all wells. Pollution by nitrates two regions showed that the ground water is strongly affected M'nasra zone terms of the permeability of the soil of the city. The concentration of nitrate can reach high values compared to the results obtained on the ground water at Sfafaa zone whose nitrate concentrations around $20 \mathrm{mg} / \mathrm{l}$. Further pollution of groundwater in the two regions of the shows values of organic matters that go far beyond the standards of drinking.
\end{abstract}

\section{Introduction}

Groundwater contamination by nitrates $\left(\mathrm{NO}_{3}^{-}\right)$ represents a massive environmental problem. From today, $\mathrm{NO}_{3}^{-}$is the most ubiquitous groundwater contaminant in the world and agricultural activities are mainly blamed for these problems. Groundwater is a strategic water source for human activities. In addition to being often of large volumes, they generally provide better quality water than surface water. These waters constitute $23 \%$ of the planet's freshwater resources [1] which must be conserved and protected from all kinds of pollution.

In fact, the natural levels of nitrates in groundwater are generally very low (typically less than $10 \mathrm{mg} / \mathrm{l}$ ), but their concentrations increase with human activity such as agriculture (nitrogen fertilizers), domestic effluents, leachates from landfills, etc. This increase is the main cause of degradation of groundwater quality and mainly of more vulnerable water tables.
In general, nitrates move relatively slowly in soil and groundwater: there is a lag time of approximately 20 years between pollution activity and detecting the pollutant in groundwater. For this reason, it is anticipated that routine pollution activities will continue to affect nitrate concentrations for several decades. However, if the pressure in the aquifer is high, transport can be very fast in the saturation zone.

In the Gharb region of Morocco, nitrate concentration in some wells reach $130 \mathrm{mg} / \mathrm{l}$ due to intensive agricultural practices [2]. Vulnerable aquifers are frequently located in zones of high water demand, such as coastal areas (Algeria, Italy, France, Morocco, Tunisia, etc). Besides, irrigated farming accounts for a large share of total water withdrawals: $83 \%$ in Greece, $68 \%$ in Spain, $57 \%$ in Italy, and $52 \%$ in Portugal [3]. The drip irrigation system is more and more encouraged by the Moroccan government via $80 \%$ of subvention. The mismanagement of irrigation can result in water misuse and also in strong negative impacts on the environment, such as nitrate pollution and eutrophication. 
The objective of this work is to evaluate and compare the groundwater pollution of two zones of M'nasra and Sfafaa (plain of Gharb) by nitrates. This study will subsequently raise the awareness of leaders to implement a plan of action to minimize the vulnerability of groundwater in Morocco.

\section{Description of the study area}

\section{Geographic location}

The surface area of the Gharb region is $600 \mathrm{Km}^{2}$. The region of M'nasra is dominated by sandy and clayey soils. The climate is Mediterranean with annual precipitations ranging between 480 and 600 $\mathrm{mm}$, and the average temperature is $27^{\circ} \mathrm{C}$ in summer and $13^{\circ} \mathrm{C}$ in winter (Office Régional de Mise en Valeur Agricole du Gharb, 2017). Eighteen water samples were collected from 18 wells (less than $50 \mathrm{~m}$ depth) installed in 19 sites located on the coastal zone of M'nasra in Gharb region, Northwest of Morocco (Figure. 1). The levy has been carried out in the periods the summer during 2017.

The Sfafaa zone belongs to the Province of Sidi Slimane, located around the geographic coordinates $34^{\circ} 15^{\prime} 0^{\prime \prime}$ and $6^{\circ} 9^{\prime} 36^{\prime \prime}$. It is limited to the North by the Province of Sidi Kacem, in the South-east by the rural commune of Boumaiz (Province of Sidi Slimane), and to the West by the rural commune of Kecybia (Province of Sidi Slimane). The zone of Sfafaa extends over approximately $197 \mathrm{~km}^{2}$. The samples of water wells were collected during the summer2014.The mean
Water samples were collected in 11 clean plastic bottles and stored in the freezer $\left(-10^{\circ} \mathrm{C}\right)$ until their analysis.

Geology

Concerning the pedo-landscape, our study zone is a part of the Vertisol domain of the Gharb region, with alluvial deposits from the Quaternary, mainly of the Late Pleistocene and Holocene.

In general, the Gharb plain is a depression between two major structural domains: the Primary Meseta to the South and the Rif mountains to the North and the East. This plain is mainly marked by geological subsidence of the Middle and Late Miocene. The Gharb load is contemporary to the Rif mountains uprising, which caused enormous landslides. The East of the Gharb plain, corresponding to our area of study, is an accumulation zone of Quaternary continental sediments, alternately coarse (cobble and gravel) and fine (silts and clays), following climate cycles. The distribution of these deposits is very heterogeneous both laterally and vertically.

annual precipitation of $386.4 \mathrm{~mm}$. We have prospected 17 wells, belonging to the Sfafaa zone.

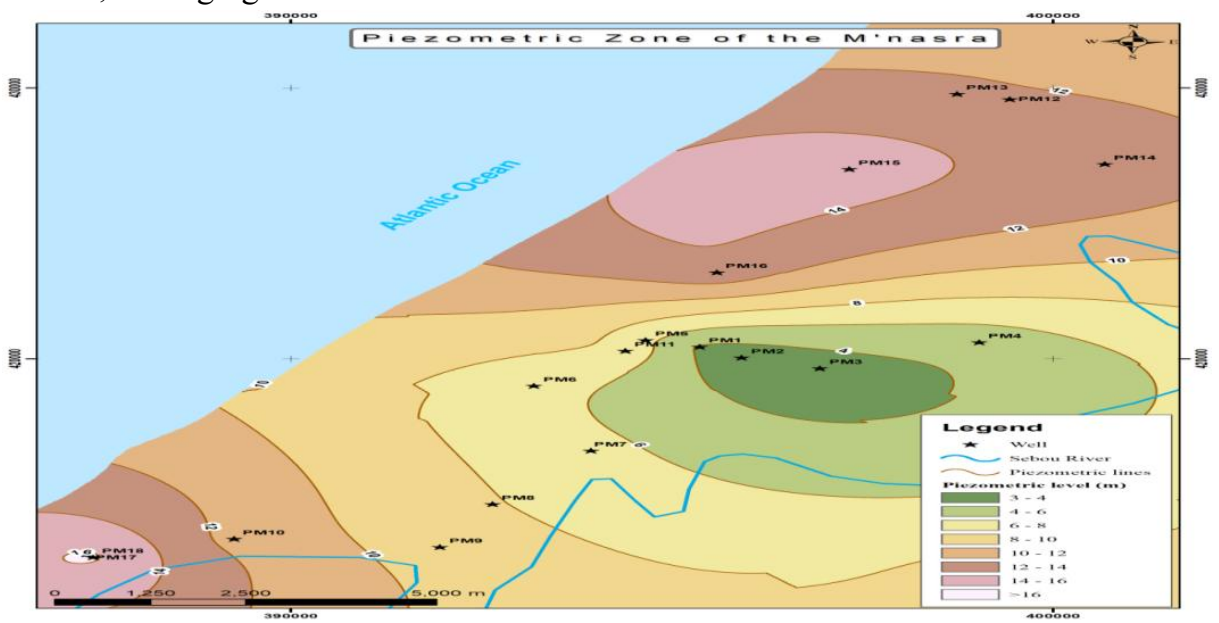

(a) Piezometric map of the M'nasra zone. 


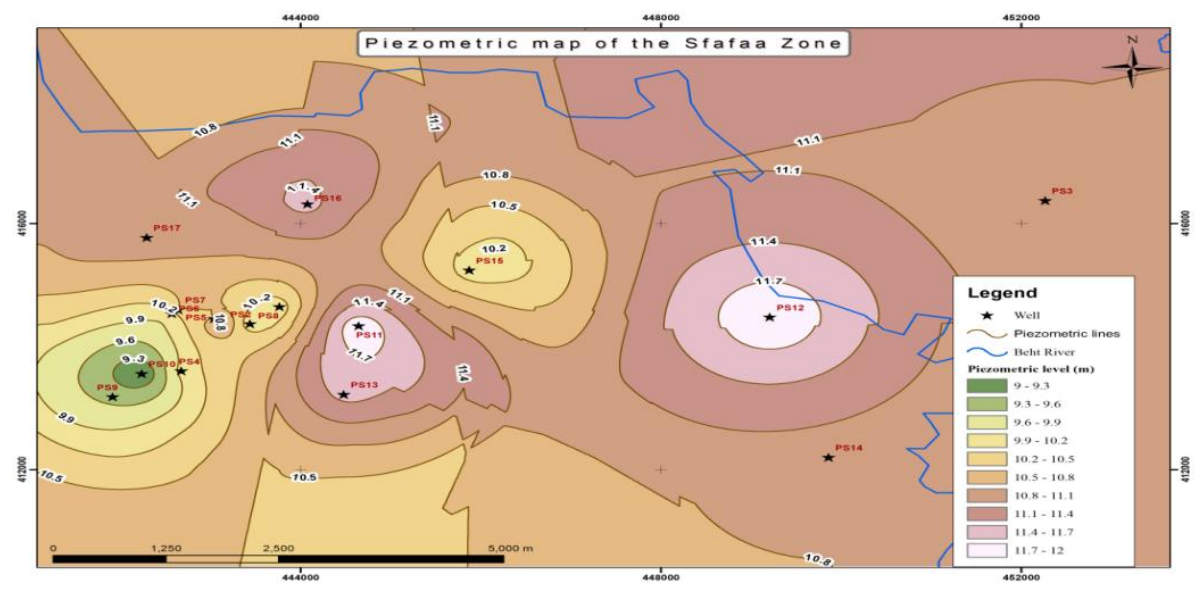

(b) Piezometric map of the Sfafaa zone.

Fig. 1. Piezometric maps of the two regions chosen for the study.

The main crops groun in the study area are field crops, vegetable crops (potatoes, tomatoes, etc) wheat etc (M'nasra and Sfafaa).

Table 1. Applied Fertilizer Doses for Main Crops
Table 1 summarizes the main crops and fertilizer doses applied at the national level [4].

\begin{tabular}{|c|c|c|c|c|c|c|c|c|}
\hline \multirow[t]{2}{*}{ Crops } & \multirow{2}{*}{$\begin{array}{l}\text { Area } \\
\text { (Ha) }\end{array}$} & \multicolumn{3}{|c|}{$\begin{array}{c}\text { Quantity of fertilizer } \\
(\mathrm{Kg} / \mathrm{Ha})\end{array}$} & \multirow{2}{*}{$\begin{array}{l}\text { Frequency } \\
(\%) *\end{array}$} & \multicolumn{3}{|c|}{$\begin{array}{c}\text { Total fertilizer quantity } \\
\text { (Tonne) }\end{array}$} \\
\hline & & $\mathrm{N}$ & $\mathrm{P} 2 \mathrm{O} 5$ & $\mathrm{~K}_{2} \mathrm{O}$ & & $\mathrm{N}$ & $\mathrm{P} 2 \mathrm{O} 5$ & $\mathrm{~K}_{2} \mathrm{O}$ \\
\hline $\begin{array}{l}\text { IRRIGATED } \\
\text { * Sugar Crops }\end{array}$ & $\begin{array}{c}33.423 \\
7.400\end{array}$ & & & & & $5.853,82$ & $2.949,87$ & $3.274,3$ \\
\hline + Sugar Cane & 5.200 & $175-200$ & 55 & $35-102$ & 100 & $910-1.040$ & 286 & $182-530,5$ \\
\hline + Sugar Beet & 2.200 & 155 & 126 & 63 & - & 341 & 277,2 & 138,6 \\
\hline * Cereals & 5.556 & $67-97$ & $42-56$ & $21-28$ & - & $372,2-539$ & $233,4-311,1$ & $116,6-155,7$ \\
\hline * Vegetable & 8.265 & & & & & & & \\
\hline+ Industrial tomato & 1.417 & $153-400$ & $200-250$ & $288-440$ & 100 & $216,8-556,8$ & $283,4-396,7$ & $428-623,5$ \\
\hline+ Potato & 2.719 & $296-600$ & $50-255$ & $110-350$ & - & $805-1.631,4$ & $136-693,3$ & $293-951,6$ \\
\hline + Strawberry & 1.624 & $160-400$ & $100-140$ & $70-155$ & - & $259,8-641,6$ & $162,4-227,4$ & $113,7-251,7$ \\
\hline +Melon -Watermelon & 1.650 & 60 & 28 & 14 & - & 99 & 46,2 & 23 \\
\hline+ Niora & 8.55 & $130-160$ & $114-225$ & $180-220$ & - & $111,2-138,8$ & $97,5-192,4$ & $153,9-188,1$ \\
\hline *Peanut & 10.283 & $115-180$ & $0-80$ & $0-85$ & - & $1.263,1-1.977,1$ & 878,7 & 933,6 \\
\hline * Citrus & 1.919 & $54-132$ & $45-54$ & $94-96$ & - & $103,6-253,3$ & $86,35-103,6$ & $180,4-184,2$ \\
\hline RAINFED & 99.252 & & & & & $3.227,4$ & $1.841,64$ & 907,24 \\
\hline * Sugar Crops & 2.075 & 155 & 126 & 63 & 100 & 321,6 & 261,45 & 130,72 \\
\hline * Cereals & 59.067 & $60-67$ & $28-42$ & $14-21$ & 60 & $2.126,4-2.374,5 \mid$ & $992,3-1.488,5$ & $496,2-744,2$ \\
\hline * Leguminous & 7.744 & 14 & 28 & 14 & 10 & 10,85 & 21,7 & 10,85 \\
\hline * Forages & 9.376 & 60 & 28 & 14 & 30 & 168 & 78,4 & 39,2 \\
\hline * Vegetable (Melon) & 6.092 & 60 & 28 & 14 & 60 & 219,3 & 102,34 & 51,17 \\
\hline * Sunflower & 6.847 & 60 & 28 & 14 & 60 & 246 & 114,8 & 57,4 \\
\hline * Olive tree & 8.051 & 14 & 28 & 14 & 10 & 11,2 & 22,54 & 11,2 \\
\hline Total Area & 132.675 & & & & & $9.131,22$ & $4.791,51$ & $4.181,54$ \\
\hline
\end{tabular}

$(\%)^{*}$ : Frequency of use by farmers. 


\section{Material and Methods}

\subsection{Characteristics of groundwater sampling points}

The present study is conducted on a network of 35 stations spread over two regions in the Gharb Plain M'nasra (Kenitra) and Sfafaa (Sidi slimane) (Figure 2). The stations were chosen according to their representativity in relation to the urban perimeter of the two cities, agricultural zones (M'nasra and Sfafaa) and their proximity to the sources of pollution (industrial zones or Ouled Berjal waste discharge). The geographical distribution is as follows:

-PM1, PM2, PM3, PM4, PM5, PM6, PM11 and PM16 stations located between the Sebou River and the Atlantic Ocean.

- Stations PM7, PM8, PM9, PM10, PM11, PM17, PM18 located after the public landfills (Ouled Berjal).
- PM12, PM13, PM14 and PM15 stations located in the North East of the M'nasra zone (upstream of Sebou).

- PS1, PS2, PS3, PS4, PS5, PS6, PS7, PS8, PS9, PS10 and PS11 stations located in the center of the Sfafaa zone.

- PS12, PS13 and PS14 stations located upstream of Oued Bhet (Sidi Slimane).

- PS15, PS16 and PS17 stations located downstream of Oued Bhet (Sidi Slimane).
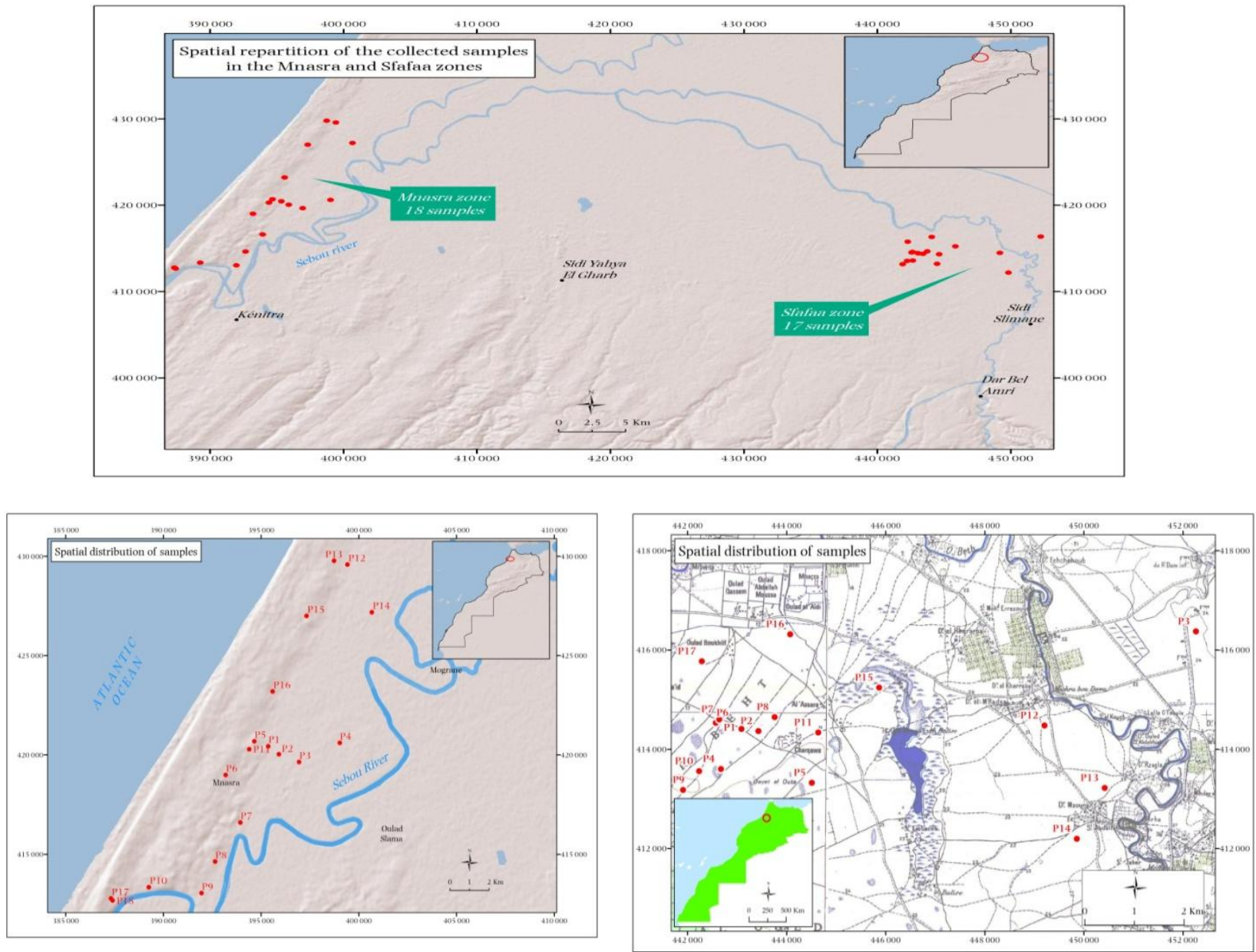

Fig. 2. Map of the M'nasra and Sfafaa zones with the sampling points. 


\subsection{Sampling and laboratory analysis}

The measurement of electrical conductivity (EC) and hydrogen ion concentration $(\mathrm{pH})$ were performed in situ using the Jenway $3510 \mathrm{pH}$-meter. Chloride $\left(\mathrm{Cl}^{-}\right)$was measured by the titrimetric method. Nitrates $\left(\mathrm{NO}_{3}^{-}\right)$was determined using Jasco V-530 UV/VIS spectrophotometer. Sodium $\left(\mathrm{Na}^{+}\right)$was determined using the Jenway Clinical PFP 7 flame photometer and oxidizability by $\mathrm{KMnO}_{4}$. Those measurements were performed according to the AFNOR standards [5].

\subsection{Statistical analysis}

First of all, a matrix of Pearson correlation coefficients between any two variables was computed and the coefficients were tested for their statistical significance. We then used Principal Component Analysis [6], a multivariate analysis technique that provides an excellent means for gaining useful information from data sets with many variables [7]. In particular, PCA can aid in the compression and classifcation of data. The purpose is to reduce the dimensionality of a data set by finding a new set of variables, smaller than the original set of variables, which nonetheless retains most of the sample's variance. Success relies on the presence of correlations among at least some of the original variables; otherwise, the number of new variables will be almost the same as the number of original variables. The new variables, called principal components, are uncorrelated, and are ordered by the fraction of the total variance each retains. The PCA was performed in this study using SPSS 20.

\section{Results and discussion}

\subsection{Parameters Physicochemical}

Human activities exercise much polluting pressures on surface water, then deferred to the water table. This deterioration in the quality of certain nitrate wells in the aquifer could be attributed to point and dispersal releases of livestock products and wastewater that has not been previously treated. Certain factors seem to favor this contamination such as the shallow depth, the permeability of the soil, the speed of infiltration, the proximity of public landfills, industrial zones, etc. Deep aquifers indirectly bound to the soil surface are therefore better protected against nitrate leaching, in contrast to shallow aquifers, which are more vulnerable because of their shallow depth which facilitates contact between leached nitrates and groundwater [8]. Contamination of the water table could cause many diseases in the population using groundwater as a source of drinking water. The effects on human health of acute poisoning by nitrates are now known, which is not the case of long-term effects.

The results obtained showed that the $\mathrm{pH}$ varies between 7.4 and 8.1 for the aquifer of the M'nasra zone, whereas for the 17 wells in the Sfafaa zone, the $\mathrm{pH}$ admits a minimum value of 6.6 and 7.4 as the maximum value. The $\mathrm{pH}$ values thus measured for the two zones chosen for the study are safe for the consumer (Figure 3).

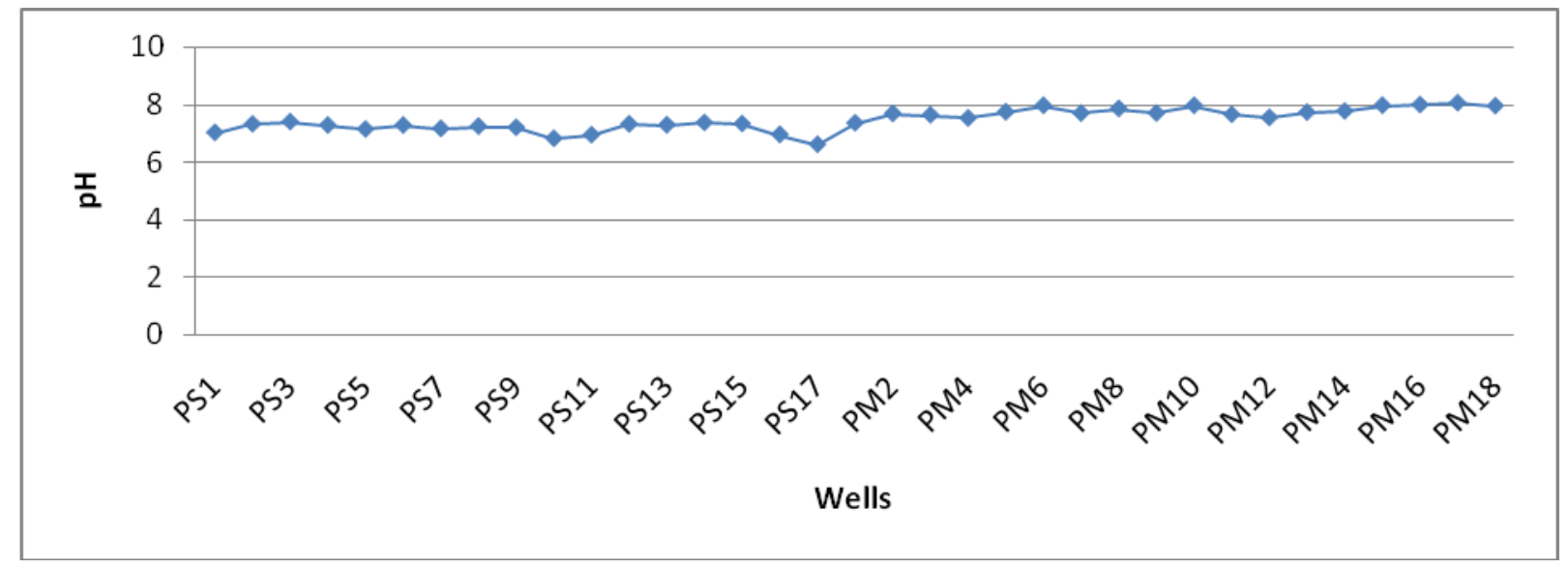

Fig. 3. Variation of $\mathrm{pH}$ values.

Electrical conductivity is used to evaluate the rate of mineralization of the environment. The higher the conductivity, the more water is strongly mineralized. The results of this study show that some wells in the Sfafaa zone (PS16, PS15 and PS12) are highly mineralized. The values are 
between 370 and $6110 \mu \mathrm{S} / \mathrm{cm}$. In addition, the groundwater conductivity at the M'nasra zone shows a maximum value of $1269.5 \mu \mathrm{S} / \mathrm{cm}$. At the Sfafaa zone, well water is mainly used for irrigation in the region. This is accompanied by a high salinity, in particular the PS16 well which has a concentration of $1184.62 \mathrm{mg} / 1$ in $\mathrm{NaCl}$ (Figure 4) while the other wells have concentrations varying between 33.93 and $477.95 \mathrm{mg} / 1$. In addition, the salinity for the wells in the M'nasra zone varies between 53.31 and $319.4 \mathrm{mg} / 1$.

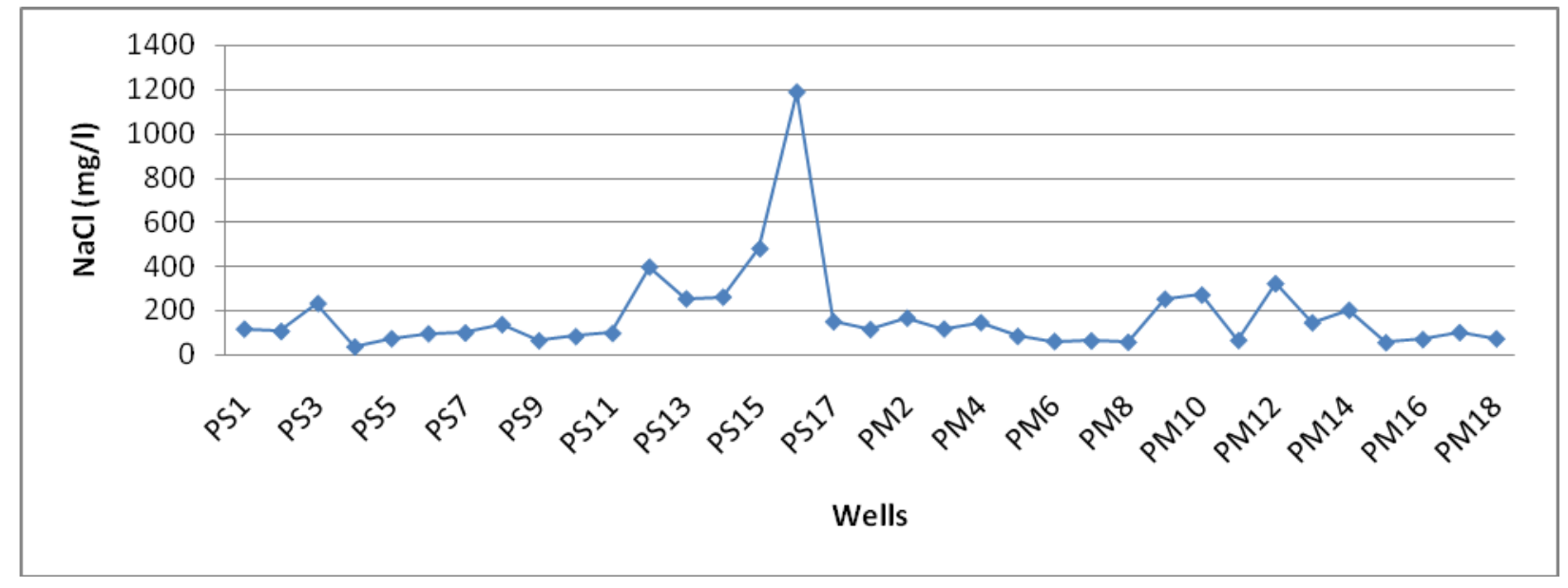

Fig. 4. Variation in the concentration of $\mathrm{NaCl}$.

\subsection{Nitrate pollution}

Domestic and urban discharges contribute locally to nitrate contamination of aquifers, but fertilization by the application of chemical or organic nitrogen fertilizers and intensive animal husbandry (animal waste) constitute the main cause.

Excess nitrates in soil are driven every year a little deeper, mainly by winter rains. The rate of migration of nitrates to the aquifers is slow, on average 1 to $2 \mathrm{~m}$ / year, but varies according to the nature of the subsoil. The excess of nitrogen spread on the surface therefore takes on average 10 to 20 years to reach a water table $20 \mathrm{~m}$ deep [9]. On the surface of the soil, organic and mineral elements alter cycles of water, carbon and nitrogen on a global scale. These transformations involve multiple risks to human health, aquatic spaces, biodiversity and agricultural productivity. The challenge for agriculture is therefore to produce more respectfully less using water resources, with respect for biodiversity and greenhouse gas emissions [10].

Nitrates and nitrites are not carcinogenic if they do not exceed WHO standards, but their possible transformation into $\mathrm{N}$-nitroso compounds in water or food before ingestion, or in the body after ingestion, could increase the risk of cancer and fetal malformation (teratogenicity) in humans [1011].The results obtained for the nitrate analysis for the two study zones showed that the concentrations for 18 sampling points in the M'nasra vary between 49.6 and $198.4 \mathrm{mg} / 1$ whereas those detected at the wells of the Sfafaa zone range from 0 to $40.9 \mathrm{mg} / 1$ (Figure 5).

For the M'nasra zone, it is noted that the wells near the Ouled Berjal landfill and the Kenitra industrial zone are loaded with nitrates with values that go well beyond drinking water standards. However, all the wells in the Sfafaa zone, far from pollution sources, have nitrate concentrations that are below the WHO standard (50 mg / 1) [10].

However, in the highly fissured geological formations, the rains reach the aquifer in a few hours to a few months, this is the case of the M'nasra zone whose soil has cracks, whereas in the less permeable formations it is will take several tens or even hundreds of years. 
Nitrogen inputs, if they are higher than plant exports, represent surpluses likely to flow to rivers and aquifers. In 2010, nitrogen surpluses ranged from 5 to $145 \mathrm{~kg}$ / ha of utilized agricultural area (UAA), with an average of $32 \mathrm{~kg} / \mathrm{ha}$ [4]. In addition, it has been shown that the risk of pollution of the Tadla water table is aggravated, for vegetable crops, by the regular application of manure at doses up to $80 \mathrm{~T} /$ ha [12]. This shows that the mismanagement of fertilizer products can contribute to the increase in groundwater pollution and subsequently the infiltration of soluble substances not retained by vegetation: excess cases in relation to its needs. The regions most affected by nitrogen pollution were those of intensive farming with a high load of organic nitrogen due to animal effluents, those of heavily fertilized field crops and those with shallow water resources (basement areas with low permeability basements, alluvial aquifers, karst aquifers) [13].

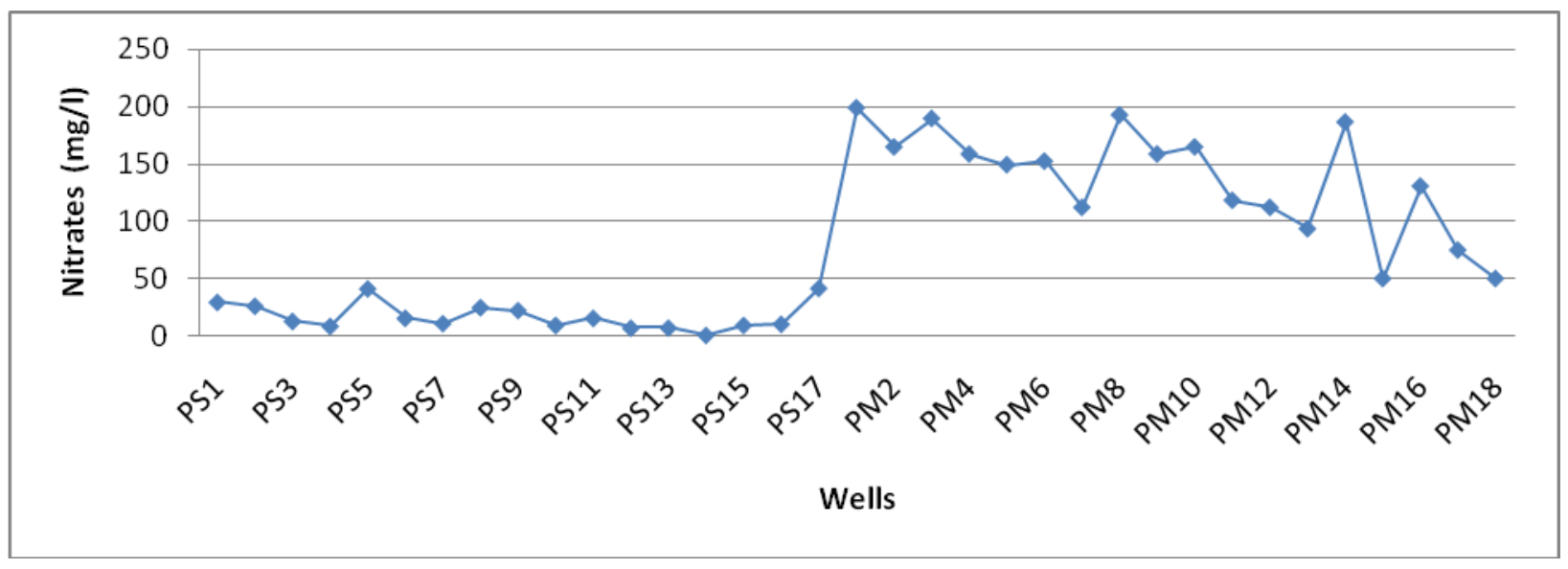

Fig. 5 . Variation of nitrate concentration.

Although, the water table in the M'nasra zone has higher levels compared to the Sfafaa zone, the nitrate pollution is high this may be due to contamination by the largely developed industrial activities in the city of Kenitra, but also by leachates from the city's uncontrolled Ouled Berjal landfill[14].

The vulnerability of groundwater depends mainly on the countries and regions because in reality the essential variable to be considered is the renewable resource and, that is to say the volume that recharges the groundwater each year [15]. In addition, the results of the physicochemical analysis in the leachate of several discharges have shown a high contamination of organic salts and heavy metals at Egypt [16]. In addition, it has been shown that in Romania landfills can represent potential sources of pollution for surface water and groundwater [17, 18]. It is for this reason that the development of new disposal areas is of utmost importance. Leachate percolation from landfill waste is a source of pollution of groundwater resources by infiltration, thus constituting a threat as important as that related to the increasing water deficit. The city of Larache landfill is a typical model of deterioration of water resources through a leachate contamination from the landfill and agricultural practices [19].

The results obtained on the pollution of the water table of the city of Taza showed a more or less strong degradation especially downstream of the city discharge [20]. The analysis of ground and surface waters revealed that nitrate ions have a mean concentration of less than $50 \mathrm{mg} / 1$ with temporal variations of remarkable amplitude (standard suggested by WHO) [14,21].

\section{Organic matter by oxidizability by $\mathrm{KMnO}_{4}$}

This parameter is used to evaluate the organic matter content in the well water. In fact, the organic matter present in the wells varies considerably from one well to another. In the well waters of M'nasra zone, it varies between 2.2 and $10.6 \mathrm{mg} / 1$ whereas those in the Sfafaa zone have a minimum of $0 \mathrm{mg} /$ 1 and a maximum of 9.9 (Figure 6). However, these values show that $57.1 \%$ of well water cannot be used as a source of drinking water. 


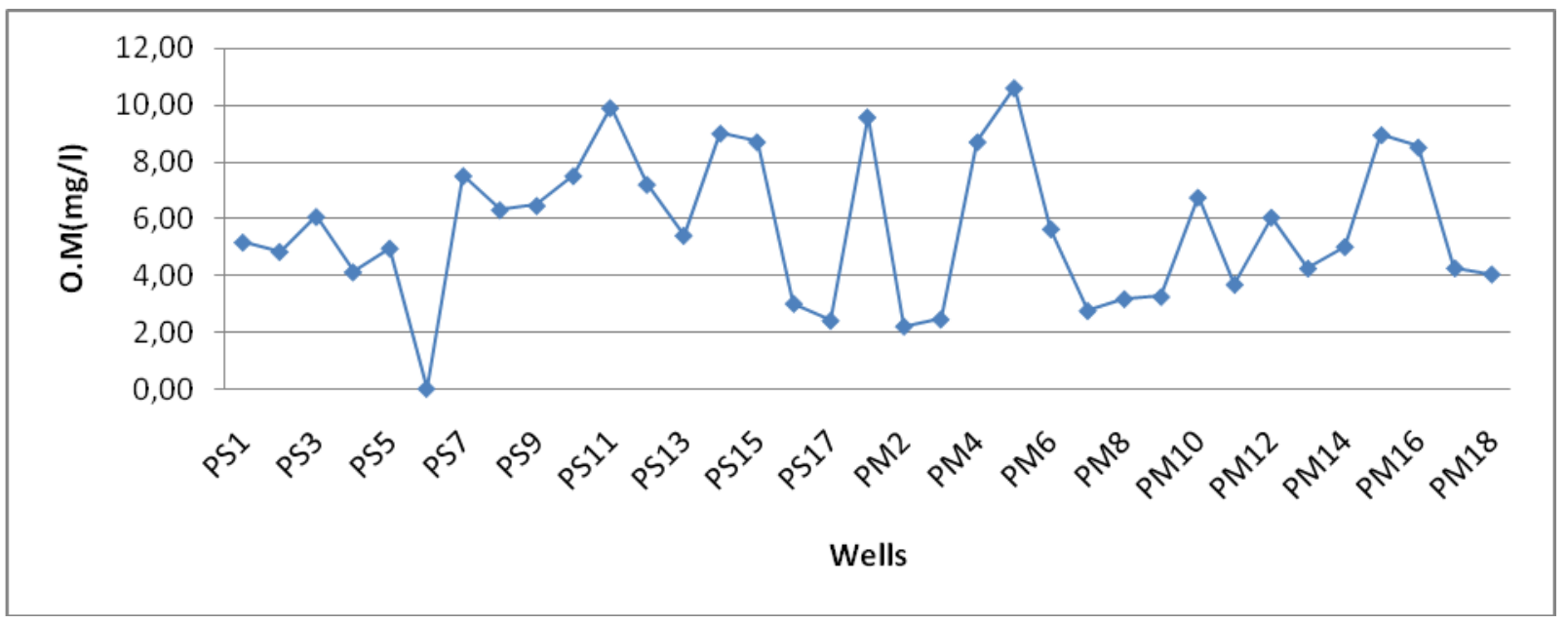

Fig. 6 . Variation of Organic Matter.

\subsection{Multivariate statistical analysis of physicochemical parameters}

Physicochemical parameters (variables) and water points (individuals) were projected separately in the factorial plane (PC1xPC2) of the principal component analysis (PCA) to better understand their representative distributions with respect to the factorial axes. The interpretation of the statistical analysis by the PCA has been done only on two axes $\mathrm{PC} 1$ and $\mathrm{PC} 2$ because they alone contain more than $70 \%$ of the information. $\mathrm{PC} 1$ axis presents $47.8 \%$ and the PC2 axis presents $23.4 \%$ of the total inertia (Figure 7). The PCA allowed us to characterize 2 groups of chemical elements each corresponding to a set of groundwater samples with the same characteristics.

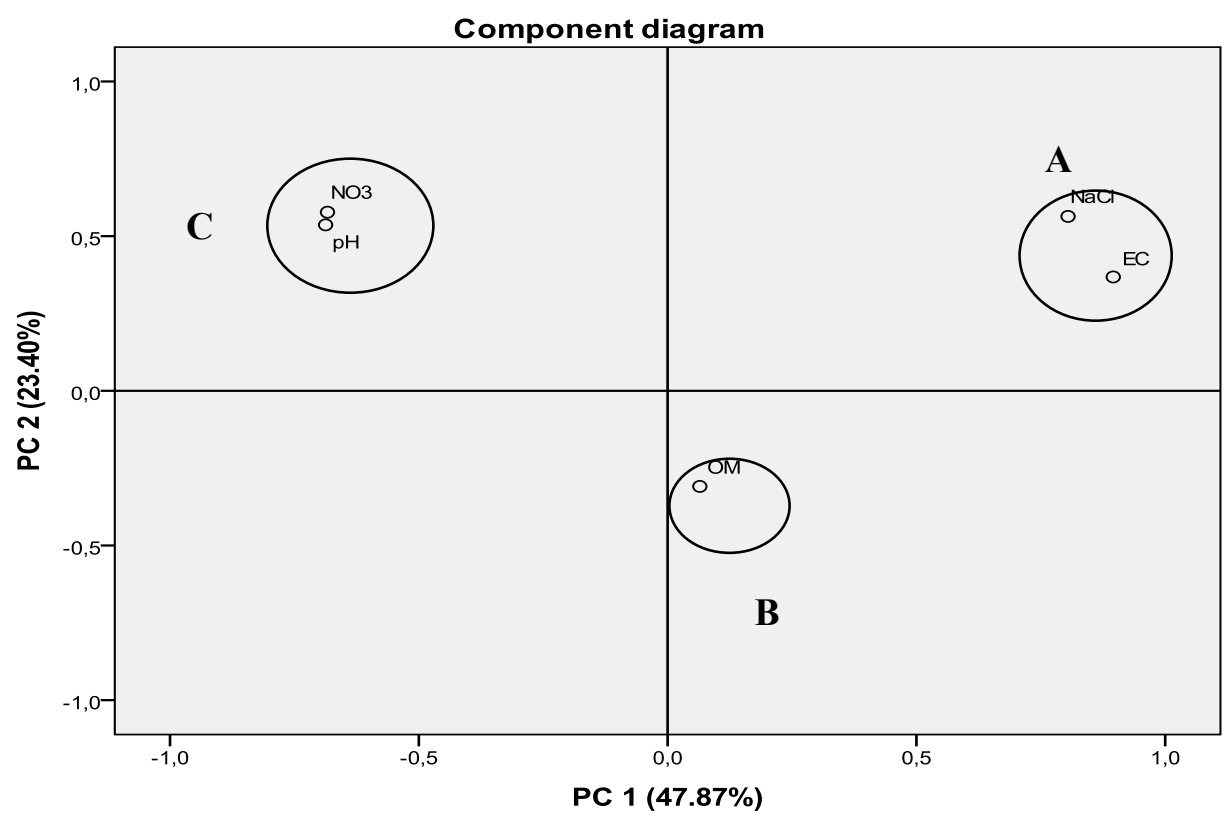

Fig. 7 .Loading plot for the principal component analysis: groundwater properties in the PC1-PC2 plan.

Groups A: This group consists essentially of $\mathrm{NaCl}$ and the electrical conductivity (EC) opposed to $\mathrm{pH}$ and nitrate along the $\mathrm{PC} 1$ axis. These parameters correspond to the set of wells consisting of PS12, PS15 and PS16 (Group 1) and which has a very 
high conductivity and salinity and very low $\mathrm{pH}$, nitrates (Figure 7).

\section{Groups B:}

This group is formed by organic matter. It is placed in negative position on the PC2 axis. This setting characterizes the PS1, PS2, PS3, PS4, PS5, PS6, PS7, PS8, PS9, PS10, PS11, PS13, PS14, and PS17 wells (Group 2).

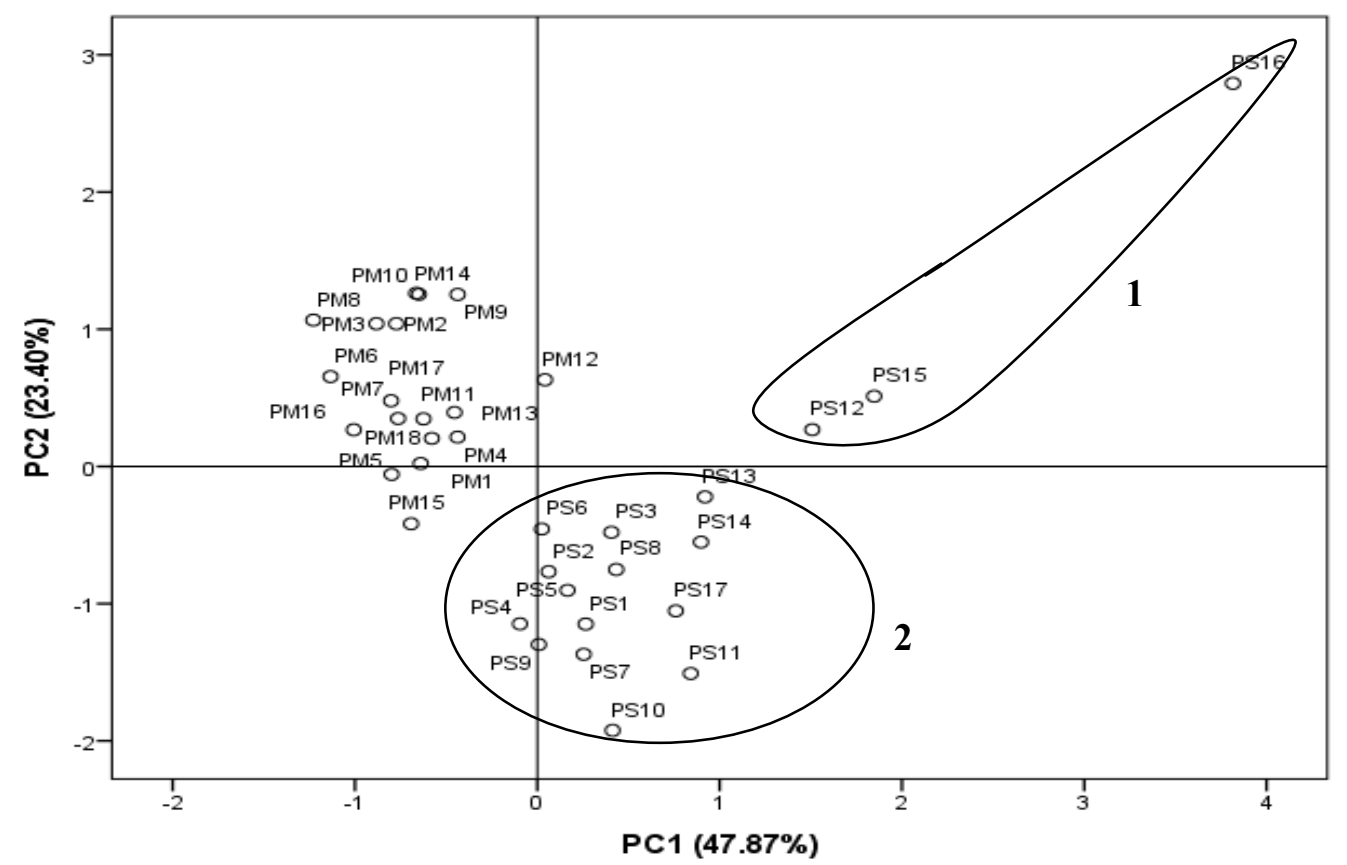

Fig. 8 . Score plot for the principal component analysis: water samples in the PC1-PC2 plan.

\section{Conclusion}

The results obtained have shown that parameters such as salinity, conductivity, and nitrates far exceed drinking water standards. The concentration of nitrates in the well waters of the M'nasra zone varies around $150 \mathrm{mg} / 1$ whereas those detected in the wells of the Sfafaa zone are close to $20 \mathrm{mg} / 1$.

Groundwater in the M'nasra zone is more contaminated with nitrates than Sfafaa. This pollution detected at the level of the wells is mainly due to their situations in relation to the landfill and also in relation to the industry. In addition, the waters of the Sfafaa zone are more saline compared to the waters of M'nasra, especially the PS16 point which is downstream of Oued Beht. To avoid pollution of the water table, it is necessary to strike a balance between the misuse of nitrates sources and the total prohibition of them. With regard to organic matter determined by $\mathrm{KMnO}_{4}$ oxidability, $57.1 \%$ of well water cannot be used as a source of drinking water.
In order to avoid ecological and health problems, it is necessary to take concrete measures to limit the pollution of the Gharb water table (M'nasra) and to protect the health of the population in rural areas.

Based on investigations and analysis, some suggestions for solving the problem, such as best management practices for nitrogen fertiliser and improving environmental awareness, are discussed.

\section{References}

1. M. Laaouan, M.A.Aboulhassan, S. Bengamra, A.Taleb , S. Souabi, M. Tahiri, J. Mater. Environ. Sci. 7 ,4 (2016) 1298-1309

2. B. Marouane, A. Dahchour ,S. Dousset ,S. El Hajjaji , Mor. J. Chem. 2 ,4 (2014) 375-382

3. J. Berbel , J. Calatrava, A. Garrido, The Gap Between Theory and Practice (Eds: F. Molle, J. Berkoff ), Biddles Ltd, King's Lynn press, UK (2007), p. 295

4. M. Achkar, Rationalisation de l'utilisation des engrais et pesticides au Maroc, Revue H.T.E, 123 (2002) 5

5. F. Laurent, Pollutions des ressources en eau et agriculture : l'ouest de la France. In Conférence 
du Monde Diplomatique "L'eau, source de vie, source de conflits", Le Mans, Presses Universitaires de Rennes, (2005) 143-150

6. Joliffe, I.T. Principal component analysis. 2nd ed. Springer, New York (2002).

7. H. Vereecken, and M. Herbst. Statistical regression. Dev. Soil Sci.30 (2004) 3-18.

8. E. Hassoune, A. Bouzidi,Y. Koulali, D. Hadarbach , Bulletin de l'Institut Scientifique, Rabat, section Sciences de la Vie, 28 (2006) 61-71

9. Commissariat Général au Développement Durable., L'eau, source de vie, source de conflits, Conférence du Monde Diplomatique, (http://www.developpementdurable.gouv.fr/ IMG/pdf/LPS161. pdf, 161(2013) 2-4

10. World Health Organization., Guidelines for drinking water quality, 2nd Recommendations. Genève, (1993)

11. P. Levallois, D. Phaneuf, La contamination de l'eau potable par les nitrates : analyse des risques à la santé, Revue canadienne de santé publique, 85, 3(1994) 192-196

12. H. Berdai, B. Soudi, A. Bellouti, Contribution à l'étude de la pollution nitrique des eaux souterraines en zones irriguées, Revue HTE, 128 (2004) 65-87

13. F. Laurent, Modélisation des processus et analyse des dynamiques territoriales. Habilitation à Diriger des Recherches en Géographie UMR ESO (Espaces et Sociétés) Université du Maine : Agriculture et pollution de l'eau, (2012) 1-186

14. S. Omrania, N. El Khodrani, A. Zouahri, A. Douaik , H. Iaaich, M. Lahmar, and S. El Hajjaji,. Materials Today: Proceedings 13(2019) 1092-1101.

15. I. Giroux , Contamination de l'eau souterraine par les pesticides et par les nitrates dans les régions en culture de pommes de terre, Campagne d'échantillonnage de 1999-20002001 Ministère de l'Environnement Gouvernement du Québec, (2003)

16. M. Magda , M. Abd El-Salam, I. Gaber, G. Abu-Zuid , Journal of Advanced Research, 6 (2015) 579-586

17. P. Casen, Agriculture and Agricultural Science Procedia; 6(2015) 500-505

18. A-M. Şchiopu, B.M. Robu, I. Apostol, M. Gavrilescu ,. Environmental Engineering and Management Journal. 8 , 5 (2009) 1155-1164

19. H. Er-Raioui, S. Bouzid, S. Khannous , M.A. Zouag , Int. J. Biol. Chem. Sci. 5,3(2011) 1118-1134

20. M. Ben Abbou, M. El Haji, M. Zemzami, F. Fadil F., Afrique SCIENCE 10 ,1 (2014) 171.
21. X. Huang, H. Deng, C. Zheng , G. Cao,. Science of the Total Environment.543 (2016) 357-372. 